\title{
SHARED EXPERIENCE OF THE UNIVERSITY OF SANTIAGO DE COMPOSTELA WITH FEMALE ENTREPRENEURS: «WOMAN EMPRENDE AND INNOVATIA 8.3»
}

\section{ОПЫТ РАБОТЫ УНИВЕРСИТЕТА САНТЬЯГО-ДЕ- КОМПОСТЕЛА В СФЕРЕ ЖЕНСКОГО ПРЕДПРИНИМАТЕЛЬСТВА: «WOMАN EMPRENDE AND INNOVATIA 8.3»}

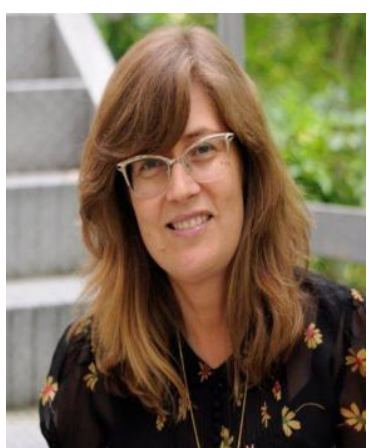

e-mail:

Abstract

Аннотация

Key words

Ключевые слова

\section{Eva LOPEZ BARRIO}

coordinator of the Innovatia 8.3, coordinator of the project of the Institute for women and equal opportunities of the University of Santiago de Compostela (Santiago de Compostela, Spain)

\section{ЛОПЕС БАРРИО Ева}

координатор инновационного проекта 8.3, координатор

проекта Института женщин и равных возможностей

Университета Сантьяго-де-Компостела (Сантьяго-де-

Компостела, Испания)

eva.lopez@usc.es

The article deals with the development of women's entrepreneurship and the role of the University of Santiago de Compostela in its development

В статье рассматриваются вопросы развития женского предпринимательства, роли Университета Сантьяго де Компостела в его развитии

higher education institutions, entrepreneurial university, women's entrepreneurship, business activity

высшие учебные заведения, предпринимательский университет, женское предпринимательство, деловая активность

\section{Introduction}

The aim of this work is to gather some of the conclusions that have been learnt at the «University of Santiago de Compostela» after dealing specifically with entrepreneurship run by female leaders, in two stages: in 2006 "Woman Emprende» Programme was created and later on, in 2011, it took the leap nationwide thanks to the «Institute for Women and for Equal Opportunities», under the INNOVATIA 8.3 brand. 


\section{Contextualization}

From everything developed, we can conclude that it is true that the context of entrepreneurial and business activities are framed into a male role action model, which women are forced to understand and, in many cases assume without discussion, if they want to be part of it.

However, it is important for women to know about the origin of many of the difficulties we face in this situations and to develop strategies, not only to face them but also to change them and to create a business activity model that takes into account the useful aspects of male and female socialization, thus contributing to building a more equal and fair society.

One of the ways to achieve this requires women to recover, recognize and estimate, as unique, the attitudes, behaviours and values derived from their socialization to «be a woman», as well as the lessons learned through the almost exclusive ownership, of domestic activities.

\section{Contents}

1. Women and entrepreneurial activity. It shows a synthesis of the current situation of women in relation to business activities. It allows identifying the most common barriers or difficulties related to gender.

2. The process of differential socialization. It briefly outlines the basic aspects that mark the subordinate position of women in a patriarchal society and explains the procedure it uses to convert people into men and women.

3. Business activity. It lists the functions of business work and compares them with the competences attributed to women.

\section{Development}

\section{WOMEN AND ENTREPRENEURIAL ACTIVITY}

Entrepreneurial activity amongst women has increased considerably in recent years (practically $30 \%$ in the last 10 years) however; their presence means approximately a quarter of the total business activity, being still far from the balance with male counterparts.

The facts defining women's business activity are:

- the small size of their companies. Most of them have either no employees or employ fewer than 5 workers, having rarely more than 50 workers. This seems to indicate that self-employment is being a way of access to employment for women who find excessive barriers or difficulties to find a paid one.

- companies are created with scarce financial and technical resources, finding themselves with difficulties and little capacity to consolidate and grow. The mortality of women's businesses is higher than that of men's companies.

- business activity is much segmented. It focuses on the services sector and within it in commerce, personal services and some business services (training, human resources ...).

On the other hand, business and entrepreneur women face some specific difficulties linked to their gender role: 
Направление 2. Сотрудничество бизнеса и вузов: лучшие европейские практики. Российский и Казахский onblm

- access to credit prevents them from undertaking large projects that require a high initial investment. This difficulty is twofold: one linked to the stereotyped view that financial institutions have on the social functions and capacities of women and the other to the relationship of women with money, used to managing only the small money of the unit of coexistence, which slows down the ability to assume risks related to investment.

- the slow or non-existent growth of their businesses due to both the difficulties of access to credit and to the lack of support from people in their living unit.

- the lack of habit to act and interact in a much masculinised environment whose codes are intimately associated with the values, attitudes and behaviours derived from male socialization.

- the virtually impossible conciliation of personal and professional life as long as all the tasks of attention and care continue to fall on women and the model of time use and work performance of business activity is organized according to male availability.

- the low awareness that women have of the capacities associated and derived from their socialization process that are useful for new business organization models.

\section{DIFFERENCIAL SOCIALIZATION PROCESS}

When women and men want to develop a business activity as well as when they wish to undertake a professional project, they start out from unequal situations due to the fact that the andocentric society in which they live assigns them different functions and roles.

The situation men and women experience in this society is articulated around the sexual division of labour and the attribution of social roles based on their sex.

This attribution of roles is carried out through a mechanism that has identified the natural, biological (giving birth) functions, typical of sex, with socially constructed functions (caretaking, attending, being a woman), typical of gender, thus articulating a socioeconomic and political system based on the identification of the concepts of sex and gender.

This reality has caused the use of spaces and times to be different for women and men. This is how public space has been reserved, that of political actions, employment, justice, etc., for men and domestic space, where they are working on reproducing life and strength for women.

The allocation of different spaces and tasks based on gender role has also influenced the organization and use of time differently by women and men. Men organize their time around the workday and outside it the rest of the time is for leisure and replenishment of their energies. Women organize it around the care of the people in the coexistence unit and, if employed, make the work day compatible with the fulfilment of domestic and family responsibilities.

Moreover, the androcentric value system places man at the centre of the universe, as a model and measure of reality, giving unequal value to women and men. To do this, it places men in a hierarchical position of superiority in comparison with women and undervalues everything that is done by them or is considered characteristic of their gender role. 
This unequal valuation has resulted in a historical discrimination against women that still survives today and which is manifested in the invisibility of women's contributions to social and economic development, in the loss of social value of activities performed primarily by women (domestic work, teaching, administrative work, etc.), in the stereotyped view of them as less capable than men for certain professional performance and, ultimately, in the existence of a whole system of structural barriers that deter equal opportunities between women and men.

The subordinate position of women in the socio-economic structure creates a great number of difficulties when they try to access, remain or be promoted in an employment, structured and organized for men's use of time.

However, in the last centuries, and especially in the last 50 years, the situation has been gradually modified, increasing the presence of women in most areas of the public sphere, reaching similar levels of training and qualification and, in some cases, superior to men. It can be said that the situation of women has improved significantly. On the other hand, if the changes in gender role are analyzed, it becomes clear that it has not undergone major transformations, since it continues to be subordinated to the productive role of men who, on the other hand, have not modified theirs.

The challenge for the future, to continue walking towards equality, must take into account that this is not achieved with a mere incorporation of women into public spaces, but it must be accompanied by profound changes in the contents and in the assessment of gender roles.

One of the ways to change this situation gradually is to retrieve values, learning and attitudes that turn out useful for developing an entrepreneurial activity and that have been generated through the process of female differential socialization.

\subsection{The differential socialization process: SPECIFIC ISSUES}

The socioeconomic model we are living in is articulated through a system of relations between women and men that is the result of a different socialization processes for each gender. Just like any socialization process, it means that people have to learn a set of values, expectations and customs of the society that they have had to live in and that will later have to be translated into a set of behaviours, attitudes and roles to play.

The process of differential socialization according to gender has survived throughout mankind history with very few modifications in its essence, although, as it was mentioned before, a change has begun in the last two centuries, especially regarding the contents of the role assigned to women as a consequence of their claims to acquire full citizenship.

However, in parallel to the modifications, this process of dissymmetric socialization is increasingly subtle, using increasingly invisible mechanisms and issuing a message of alleged equality consisting, in reality, on women assimilating the male model.

The foundations of this socialization process are built from the creation of two gender identities whose contents are different and have, as we have seen, an unequal social value since women occupy a position of inferiority to men.

The survival of this socialization model throughout history has been based on: 
Направление 2. Сотрудничество бизнеса и вузов: лучиие европейские практики. Российский и Казахский onblm

- the delivery of a single and permanent message: «how to be a man» and «how to be a woman». The content of this message dictates both the contents of the roles and the social expectations of each gender. In short, the message states what a woman or a man has to do, how they must behave and what society expects from them based on their sex.

- the use of a multiplicity of agents as channels for broadcasting the message. The process of differential socialization is carried out through various agents (family, religion, school, etc.) that, as we will see later, disseminate without dissonance and constantly the aforementioned message.

- the articulation of a process that takes place throughout the lives of people with that unique and coherent message (on how to be a woman and how to be a man). The permanence of the message runs from the moment of birth, through the allocation of colours (pink for girls, blue for boys), until the end of life, indicating what is typical of the elderly men and women.

\subsubsection{The message}

The content of the socialization process is structured through gender roles or the role that must be played socially according to whether you are a woman or a man.

The gender role includes a great mission or purpose (sustained on the sexual division of labour), a series of attitudes, behaviours and values, a priority ascription to a physical space and a use of time. All this marks a social position, based on the unequal assessment of each of the two roles.

Women, based on their biological capacity to give birth, as mothers, are assigned a reproductive role, basically characterized by:

- the attention and care of the people who occupy the domestic space, taking care of the tasks linked to the emotional support of these people. This implies dealing with education, internalization of habits, conflict regulation, etc.

- use of domestic space and carrying out maintenance, organization and planning tasks of that space. It involves taking care of the infrastructure (cleaning, for example), the tools, the supply, etc. Informal learning obtained both in this point and in the previous one has no social value.

- use of circular time, it has no beginning and no interruptions. Affective support, for example, taking care of and worrying about the balanced development of daughters and sons lacks a precise schedule.

- role dependent on the public activity of men and socially subordinated. It implies, in many cases, investing in the partner's professional career, instead of on their own, for example.

The contents of this reproductive role have a lower availability for women's employment, turning this into an option in their lives.

Men are assigned a producer role, characterized by:

- the main function of providing monetary income to the domestic sphere. This implies that employment becomes the main axis and backbone of men's life.

- use of the public space, performing all the activities of that space: politics, religion, economy ... Hence, socially recognized know-how and knowledge will be derived from here, including the informal learning obtained. 
- use of lineal time, it has a beginning and an end. It is interrupted with the beginning and the end of each task and is usually focused on the execution of only one task at a time. Men's time, in general, is distributed into working hours, leisure time and rest.

- socially independent and prominent role. It manifests in the greater social value of the male behaviour model and in the empowerment and development of risktaking initiatives and capacities.

The contents of this producer role place men before the need to generate an availability totally focused on employment that loses the optional character it has for women and becomes an obligation.

The content of this message has remained unchanged, in its essence, throughout the centuries but since the last century and especially in the last thirty years the contents of the reproductive role of women have been gradually modified by increasing their presence in public spaces. Consequently, at present, women receive a more ambiguous socialization message, in which they are still assigned the tasks derived from the domestic space, but others related to public space and the performance of employment are added, thus being socially considered as complementary to the male's employment.

\subsubsection{Transmitting the message}

The success of the socialization process lies not only in the delivery of a single message, but also in the multiplicity of agents issuing it, acting from different perspectives and throughout the entire life cycle of a person. The conjunction and articulation of these three factors contributes to perpetuate the division of gender roles. The socialization agents of with the greatest incidence are:

- the family acts mainly in the affective side of people and delivers its socializing message through games and toys, through models of men and women represented as father and mother, the reinforcement or punishment of different attitudes and behaviours, the manifestation of future life expectations for girls and boys, colour assignment,... Boys and girls are progressively internalizing the contents of their roles, develop tastes and abilities either related to the manipulation or to taking care and attention of female and... male dolls. As a result, the foundations are progressively being laid for children, teenagers and youth to meet social gender expectations.

- the school, acts more on the cognitive side of people and although it does not apparently discriminate against girls, it subtly reinforces their reproductive and subordinate role: teacher-student interaction reinforcing behaviours and uses of space and tools according to gender, assigning tasks according to whether they are boys or girls or just being guided by academic expectations (girls are good at languages and boys are good at mathematics...); the impact of textbooks, very often with sexist content, images and language, etc. As a consequence, the circle narrows a bit more, with boys increasing their capacities and skills linked to abstraction and girls increasing theirs linked to communication and mediation.

- the «peers group». It also acts on the affective side and reinforces previously internalised models by the intervention of the previous agents. It uses punishment 
Направление 2. Сотрудничество бизнеса и вузов: лучиие европейские практики. Российский и Казахский onblm

(expulsion, isolation, ridicule) if the role and social expectation of gender is transgressed, together with the reinforcement of non-transgressive behaviour. Consequently, boys continue to develop greater aggressiveness and eagerness to conquer, and girls, with the exception of recent assimilations of boys, continue to play their role as conciliators (good and «modest»).

- religion acts mainly on the spiritual side and in the symbolic world, issuing messages not only about the right moral behaviour for each gender but also showing symbolic models that reinforce the gender role. Thus, for instance, the female symbolic model represents a part of a whole, through the myth of the creation of Eve from Adam's rib, while men can see themselves represented in the most powerful figure: God.

- likewise, sexual division of labour, with the assignment of roles, is symbolically represented by the divine punishment of Eve's «transgression», who wanted to attain wisdom: "You will earn your bread by the sweat of your brow and will give birth in pain.

- the language that, by using the masculine as a generic, makes women invisible, subordinates them, objectifies them, underestimates them, and excludes them from the symbolic representation operated by language. For example, the unequal and different meaning of male and female fox, the identification of women with objects. e.g. quotes like «nomadic peoples moved around with belongings, women and animals...», the invisibility or non-existence of women in sentences like «man has perpetuated the species through the domination of nature».

- media reinforces the socializing message about gender identity by choosing the content of news, reports and documentaries, adverts, etc. They show stereotyped images of women and men together with subtle mechanisms such as the use of male voices when something important or of great social value is being said and female voices when it has something to do with the gender stereotype of women, affecting that way the subordination of women. In a society like the present one, based on image and information, this agent of socialization has a great impact on the configuration and perpetuation of male and female models.

This dissymmetric socialization process is clearly ineffective at this time for a rapidly changing model of society whose economic structure is increasingly concentrated in the services area with activities requiring more mixed professional profiles and in which some of the skills derived from both female and male socialization are intermingled.

Hence, it is clear that the «ideal» profile of a working person demands nowadays a mixture of initiative, personal autonomy, decision-making and risk taking skills, teamwork skills, attention to processes, communication skills, negotiation skills, etc., that is, a set of skills in which those produced by female and male socialization coexist.

\section{ENTREPRENEURIAL AND BUSINESS ACTIVITIES}

Nowadays, companies face the need to give an answer to market transformations, which are a consequence of changes in the organizational model, of the modifications introduced in the productive processes by the automation and 
application of information technologies and of the modifications of habits and social organization.

Facing a reality shaped by changes requires a quick adaptation to the demands of those changes and this is only possible from a business model capable of learning. It requires permanent observation and analysis of the environment, seeking for opportunities and threats while knowing one's own strengths and weaknesses. Companies cannot just focus on results but they must also take into account processes and designing the most profitable procedures. A business model is needed in which learning is paramount to its activity.

The most capable kind of people to manage and perform their jobs in this business model are those whose profile includes skills related to flexibility, change orientation, listening and communication skills. Those people must be able to look outwards (not inwards) and develop a participatory working style.

Women, as explained above and excepting individual differences, are usually characterized by having a gender profile that is quite close to the requirements of the new business model: they are flexible and versatile, they adapt to different realities, they have the ability to manage several issues simultaneously, have verbal fluency and active listening skills to communicate and by being able to give and ask for advice, they are able tolerate the mistakes of others and to allow the creation of a cooperative and participatory working environment.

\subsection{Business activities roles}

If we compare at this time the functions that the direction and management of a company entails with women profiles derived from their socialization as well as from their domestic activity we find the following reality.

1. Interpersonal roles. Business activities require a variety of roles related to these functions:

- representing the entity, for which is necessary taking care of the external aspect, knowing the rules and patterns of behaviour in forums and situations in which the company is present as an entity. Women have the basic knowledge of this because they are used to representing the interests of the family unit at meetings of neighbours and parents. The dimension is obviously different and that basic learning must be completed with other linked to the activity and culture of the company but they take advantage of what they have already acquired.

- guiding and accompanying groups of people when working for the company. Women manage a human team like the family so this activity is not strange to them. Their greater tolerance for other people's mistakes will facilitate it.

- interacting with groups external to the company (suppliers, banks, business organisations, trade unions, etc.). Women's domestic activity implies a permanent relationship with suppliers when buying food and domestic equipment in general, so it can be said that the basic procedure for establishing this type of relationship is already known.

2. Informative functions. Business demands:

- identifying and interpreting the opportunities and threats that the environment brings to the company. In this sense, it can be said that women have the basic abilities 
Направление 2. Сотрудничество бизнеса и вузов: лучиие европейские практики. Российский и Казахский onblm

to perceive opportunities and threats. However, although they have developed this intuitive spirit, their traditional distance from the decision-making circles and their short trajectory as businesswomen requires them to obtain enough objective information to have realistic views of the environment and its foreseeable evolution.

- issuing and spreading information throughout the organization. This activity is integrated in women's usual way of acting, as a consequence of both their socialization and their attachment to the domestic environment. Not in vain most of the internal communication departments of companies are nowadays occupied by women, showing that, in addition to technical qualifications, they have the necessary skills and abilities to carry out these tasks.

- transmitting information to the outside world regarding your organization. External communication is currently a very important business function since it affects your market positioning and therefore your customers' perception about you. The communication capacity developed by women in their socializing process allows them to have the basic skills to carry out this activity as well.

3. Decision-making functions. Despite the fact that in a company is necessary to pay attention to the whole, decision making is the central activity and involves:

- planning and controlling both the usual activity and the changes generated by the new projects which are undertaken. As it has been seen, the domestic activity has allowed women to develop the capacity of planning and organizing from an essentially practical sense as well as the capacity of responding in a pragmatic way to the unexpected. This places them in a very good position to carry out this function if they complement these basic skills with the knowledge and handling of the usual management tools in this field.

- managing conflicts arising in the daily course of a professional activity. Women, due to their socialization aimed at caring for others and their domestic activity related to conflict resolution and affective regulation, have developed an essential mediating profile to perform successfully in conflict management, being able to avoid being stuck by them, to live with them and to put together the essential elements to solve them.

- allocating resources. Pragmatic mentality, planning skills and daily administration of family income have developed amongst women a predisposition that facilitates the distribution of resources in a weighted way and according to needs.

- negotiating. The central position within the unit of coexistence for maintaining both the infrastructure and the psychological and physical balance of the members, for regulating conflicts and their role as mediators, enables women to develop their capacity for negotiation, a basic element for managing the common interest in front of the multiple interests of the people who make up a unit of coexistence, a work team or a company.

All the aforementioned translates into what is often called the female management style which, in a study about 92 managers conducted by Marcia Bombyk and Roslyn Chernesky, is based on their orientation towards people because of their ability to listen, gather information and achieve consensus. In this study, the authors identify nine behaviours that women use far more than men:

Interest in people. 
Sensitivity to the needs of working women.

Investment in the professional training of male and female workers.

Cooperative orientation.

Global perspective.

Open communication.

Recognition of other people's concerns.

Interest in the quality of the environment.

The use of intuition.

Tom Peters states that women are less hierarchical and more flexible, are group-oriented, fast-acting and generate smooth communication, and this is explained by the fact that female socialization, which is contrary to personal success and achievement above all, leads women to prioritize sharing to success, social and professional brightness.

This is reflected in their position at the centre of the company and in the inclination to structure their companies in the form of networks (groups or teams working towards a common goal) instead of formalising a hierarchical structure that is alien to them and that in any case reminds them that they are the subordinates.

All in all, it allows communication to flow in multiple directions and this less formal and more flexible structure can more easily be adapted to changes and this is essential to remain in the market.

In brief, it can be said that women provide a set of attitudes and values to business activities, as a result of both their socialization process and their performance of domestic activities, which in the current configuration of economic activity, in general, and professional activity, specifically, are very useful for solving work situations in the information society. 